\title{
Academic careers of UM alumni
}

Citation for published version (APA):

Künn, A., Bijlsma, I., \& van Eldert, P. (2018). Academic careers of UM alumni: A focus on gender differences. ROA. ROA Reports No. 003 https://doi.org/10.26481/umarep.2018003

Document status and date:

Published: 01/01/2018

DOI:

10.26481/umarep.2018003

Document Version:

Publisher's PDF, also known as Version of record

\section{Please check the document version of this publication:}

- A submitted manuscript is the version of the article upon submission and before peer-review. There can be important differences between the submitted version and the official published version of record.

People interested in the research are advised to contact the author for the final version of the publication, or visit the DOI to the publisher's website.

- The final author version and the galley proof are versions of the publication after peer review.

- The final published version features the final layout of the paper including the volume, issue and page numbers.

Link to publication

\footnotetext{
General rights rights.

- You may freely distribute the URL identifying the publication in the public portal. please follow below link for the End User Agreement:

www.umlib.nl/taverne-license

Take down policy

If you believe that this document breaches copyright please contact us at:

repository@maastrichtuniversity.nl

providing details and we will investigate your claim.
}

Copyright and moral rights for the publications made accessible in the public portal are retained by the authors and/or other copyright owners and it is a condition of accessing publications that users recognise and abide by the legal requirements associated with these

- Users may download and print one copy of any publication from the public portal for the purpose of private study or research.

- You may not further distribute the material or use it for any profit-making activity or commercial gain

If the publication is distributed under the terms of Article $25 \mathrm{fa}$ of the Dutch Copyright Act, indicated by the "Taverne" license above, 
Research Centre for Education and the Labour Market | ROA

\section{Academic careers of UM alumni A focus on gender differences}

\section{ROA Rapport}

ROA-R-2018/3

Researchcentrum voor Onderwijs en Arbeidsmarkt | ROA Research Centre for Education and the Labour Market / ROA 


\section{ACADEMIC CAREERS OF UM ALUMNI. A FOCUS ON GENDER DIFFERENCES}

ROA-R-2018/3

Annemarie Künn-Nelen

Ineke Bijlsma

Peter van Eldert 


\section{Colofon}

(c) Research Centre for Education and the Labour Market (ROA). No part of this publication may be reproduced without the prior persmission in writing of the director of the Research Centre for Education and the Labour Market.

\section{Research Centre for Education and the Labour Market}

School of Business and Economics

Maastricht University

\section{Layout}

Secretary ROA, Maastricht

\section{Sales}

Research Centre for Education and the Labour Market email: secretary-roa-sbe@maastrichtuniversity.nl

website: www.roa.nl

ISBN: 978-90-5321-566-1

March 2018 


\section{CONTENTS}

Foreword

1 Introduction

2 Data

3 Starting a PhD

4 Obtaining a PhD title

5 Continuing an academic career after the PhD

6 Gender differences in job quality between male and female alumni with a PhD

7 Conclusion

Appendix 


\section{FOREWORD}

The Research Centre for Education and the Labor Market (ROA) of Maastricht University conducts an annual survey to elicit information about the labor market position of our master alumni.

Next to the yearly factsheets on the general labour market of UM alumni, the data can also be used to shed light on a policy relevant theme. In this report, we provide insights in the academic careers of UM alumni and focus on gender differences in this respect. We first show gender differences in starting and finishing a $\mathrm{PhD}$ and in continuing an academic career after the PhD. We try to explain gender differences by satisfaction with their UM studies, by personality and by job preferences. Second, we describe gender differences in labour market characteristics of alumni with a $\mathrm{PhD}$. This policy report can be used in discussions about gender equality in the academic careers of UM alumni and may be used to evaluate and adapt UM programmes to create awareness of the gender differences in both academic and non-academic careers of UM alumni.

This report is written by Annemarie Künn-Nelen, Ineke Bijlsma en Peter van Eldert. We also relied on a master thesis written by Chantal Senden, supervised by Annemarie Künn-Nelen.

We thank the Alumni Office of Maastricht University, in particular Denise Villerius and Guido Vandenbroecke, for their support. Moreover, we thank Monique van Alphen and Han van Dongen from DESAN Research Solutions, who were in charge of the data collection within the UM alumni research project. From within Maastricht University, we would like to thank the feedback group, consisting of Hans Ouwersloot, Patricia Meertens, Denise Villerius, Saskia van Bergen, Sylvia Haerkens, Jet Custers, Lutz Krebs, Peggy Rompen, Annemarie Spruijt and Rina Vaatstra. 



\section{1 \\ INTRODUCTION}

\section{Background}

Despite the large increase in labour market participation of women over the last decades, ${ }^{1}$ large discrepancies in labour market outcomes do still exist. It concerns, among others, labour market participation ${ }^{2}$, wage differences ${ }^{3}$ and board positions. ${ }^{4}$

Large differences also exist in the academic world. The gender difference in academics increases rapidly with the job levels. Whereas $43 \%$ of the PhD students related to Dutch universities are female, only $19.3 \%$ of all professors are female., ${ }^{5,6}$ In Figure 1, one can see the so-called scissors, showing the glass-ceiling phenomenon for women in academia.

1 CBS StatLine 2016, Beroepsbevolking; vanaf 1800 (12-uursgrens).

CBS StatLine 2017, Beroepsbevolking, vanaf 2003 (1-uursgrens).

3 Blau and Kahn (2017), The Gender Wage Gap: Extent, Trends, and Explanations, Journal of Economic Literature, 55(3), 789-865; CBS (2016) Gelijk loon voor gelijk werk? Banen en lonen bij de overheid en bedrijfsleven, 2014

4 https://www.ocwincijfers.nl/emancipatie/participatie-van-vrouwen/vrouwen-in-bestuursfuncties

5 Measured in full-time equivalents.

6 LNVH (2017), Monitor Vrouwelijke Hoogleraren 2017. 


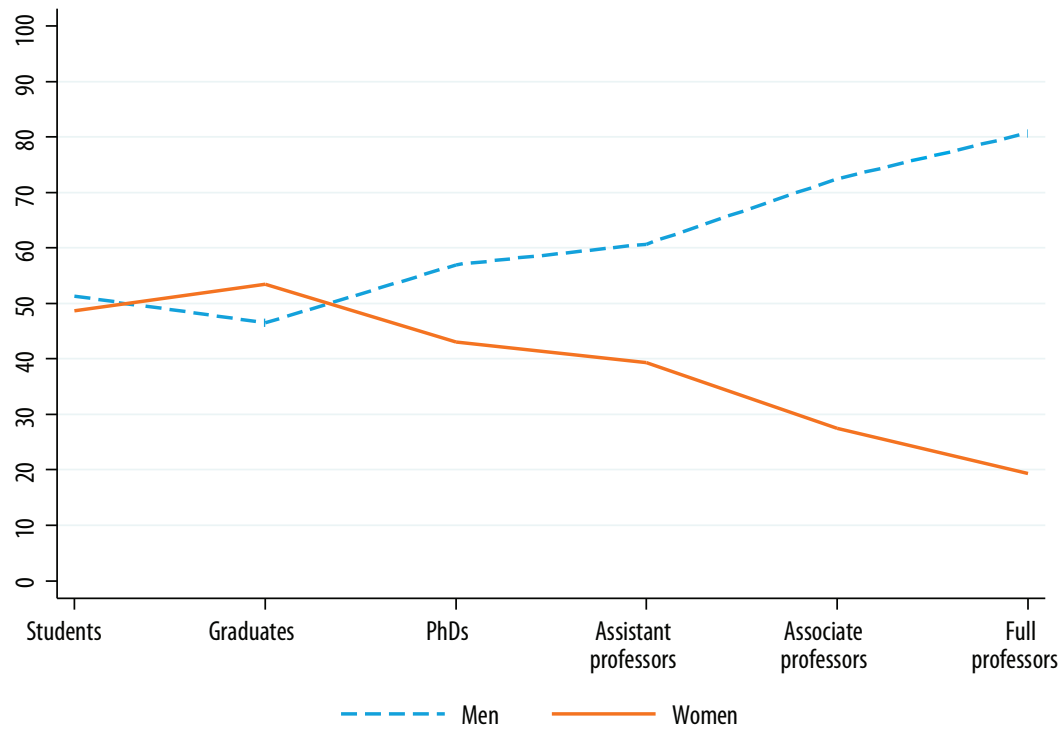

Source: Monitor Vrouwelijke Hoogleraren 2017

Next to the differences in academic job titles across men and women, gender differences also exist on the labour market among $\mathrm{PhD}$ graduates. For instance, recent research has shown that female PhD graduates more often work part-time, have a leading position less often and earn less than male PhD graduates. ${ }^{7}$ It turns out that these differences can partly be explained by family responsibilities of women. ${ }^{8}$

\section{Research questions}

In this report, three central questions with respect to gender differences of UM alumni are central:

1. What are the gender differences in starting and continuing an academic career?

2. What are the gender differences in job quality of alumni with (and irrespectively of) a PhD?

3. How can possible gender differences in academic careers of UM alumni be explained?

To comment on job quality, we look into wages, perceived career opportunities, job satisfaction, working full-time and whether someone has a leadership position. We provide descriptive statistics and report on the significance of the gender difference.

7 CBS (2016), Sekseverschillen op de arbeidsmarkt ook onder gepromoveerden, Sociaaleconomische trends, maart 2016|03.

8 Van Mol (2015), Het glazen plafond van de Nederlandse wetenschap. DEMOS, 31(9), 8. 
Moreover, we estimate regression models to see whether the gender difference can be explained by alumni satisfaction with their UM studies, by their personality and/or by their job preferences. 



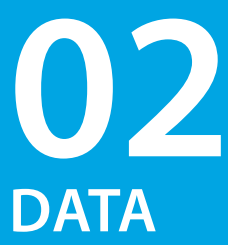

Since the beginning of the 1990s, Maastricht University has kept track of the labor market outcomes of its alumni. Every year, three graduation cohorts are surveyed: (1) alumni who graduated about 1.5 years ago, (2) alumni who graduated 5 years ago, and (3) alumni who graduated 10 years ago. The surveys primarily focus on the labor market situation of the master alumni, ${ }^{9}$ on the transition from the UM to the labor market, and on the quality of their studies through the eyes of the alumni.

For this report, we use information on respondents of the UM master alumni questionnaires from nine graduation cohorts. ${ }^{10}$ In Table 1 an overview is given of these graduation cohorts and the consecutive survey/measurement years.

TABLE $1 \quad$ Graduation cohorts per year and wave

\begin{tabular}{|c|c|c|c|}
\hline $\begin{array}{c}\text { Measurement } \\
\text { year }\end{array}$ & W+1^ & Wave & T+10 \\
\hline 2014 & $2012 / 2013$ & $2008 / 2009$ & $2003 / 2004$ \\
\hline 2015 & $2013 / 2014$ & $2009 / 2010^{*}$ & $2004 / 2005^{*}$ \\
\hline 2016 & $2014 / 2015$ & $2010 / 2011$ & $2005 / 2006$ \\
\hline
\end{tabular}

$\wedge T+1$ wave is part of the NAE (Nationale Alumni Enquete) which is carried out bi-annually (2015). However, the UM sends out surveys annually.

* As part of an initiative of the VSNU the T+5 questionnaire of 2015 was sent out to more universities. Therefore, the content of the $T+5$, as well as the $T+10$ surveys, from 2015 is different from those in other years.

In this report, we focus on several academic career outcomes.

- Starting a PhD

- Obtaining a PhD title

- Working in an academic organization

9 Or equivalent.

10 The survey is a representitative sample of the population. Response rates depend on the wave and measurement year: $T+1$ : around $23, T+5$ : around $31, T+10$ : around 34 . More information about sampling strategies, data collection and questionnaire design is available from ROA. 
- Working in an academic position

In all waves, UM master alumni were asked whether they started a PhD (at some point in time) after graduation." Information on whether alumni also obtained a PhD title can be gathered from the $\mathrm{T}+5$ and $\mathrm{T}+10$ surveys. Among those who did obtain a PhD title, we know, at the time of the survey, whether they work in an academic organization and in an academic position. ${ }^{12}$

When describing gender differences in labour market characteristics among alumni with a PhD, we focus on hourly wage, career opportunities and job satisfaction.

Taken all 9 graduation cohorts together, we have a sample of 5413 observations. From 5383 alumni we know whether they started a PhD. $59 \%$ of them are female. ${ }^{13}$

11 From now on, we refer to UM master alumni when writing down UM alumni.

12 In 2015, the (national) survey did not contain any questions about working in an academic organization and in an academic position.

13 This is in contrast to Figure 1 where the percentage of female $\mathrm{PhD}$ students is smaller than the percentage of male PhD students. This could be due to (a) a difference in starting a $\mathrm{PhD}$ across gender among UM alumni and alumni from other Dutch universities, (b) an overrepresentation of female UM alumni who did start a PhD, (c) differences over time as we include more graduation cohorts than Figure 1. 


\section{3 \\ STARTING A PHD}

In Figure 2, the percentage of men and women who started a $\mathrm{PhD}$ is shown for the UM as a whole as well as per faculty. The figure first of all shows that over all graduation cohorts and faculties together, $15 \%$ of the male alumni did start a $\mathrm{PhD}$. This is

Men and women have similar reasons not to start a PhD. About $75 \%$ had no interest in an academic career and about $8 \%$ could not find a suitable PhD position. Other reasons which were mentioned are financial constraints, family situation and another job offer. significant less than for women: among female alumni, 19\% did start a PhD. This is in contrast to the so-called scissors as described in the introduction, where women already lack behind men in the stage of a PhD.

Moreover, Figure 2 shows that there are more differences in starting a PhD across faculties than within. While the total number of female students starting a PhD is higher due to the higher number of female students within some faculties, men and women do seem to start a PhD about equally often within faculties. There is one exception: men from FHML do start a PhD significantly more often than women from the same faculty. 


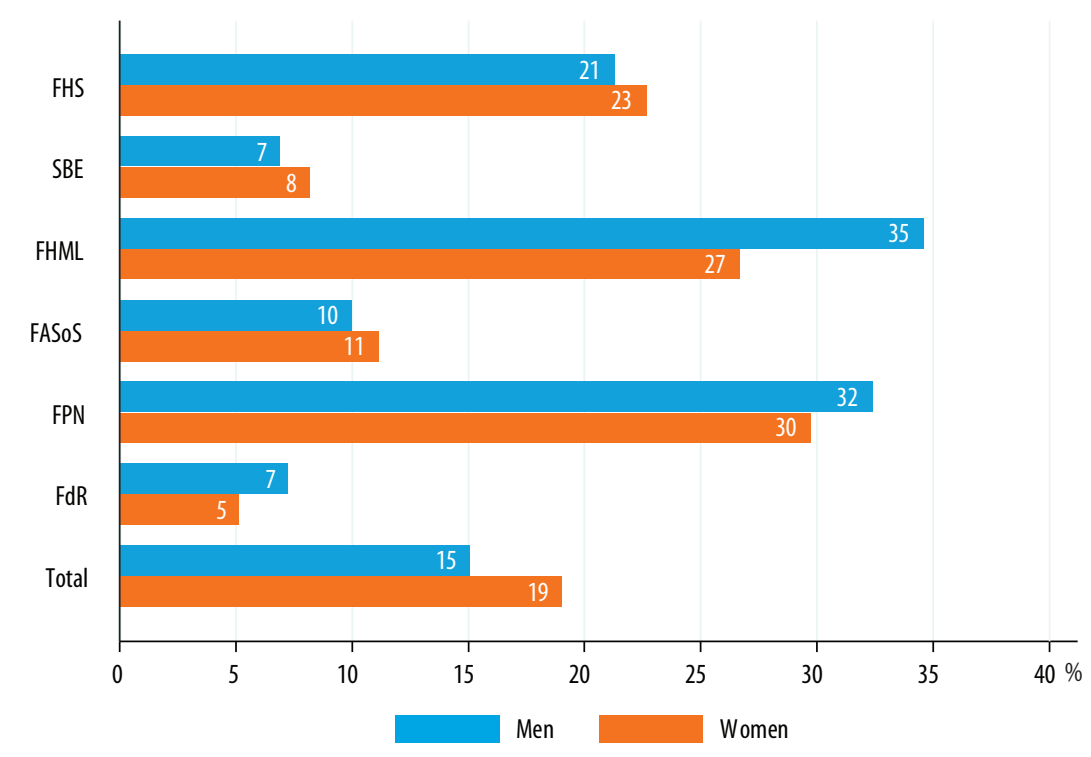

Source: NAE 2014, 2015, 2016, UM scanner 2014, 2015, 2016

In Figure 3, the overall percentage UM alumni who started a $\mathrm{PhD}$ is shown per faculty. The weighted average (based on number of male and female alumni per faculty) of the percentage men and women starting a PhD position per faculty in Figure 2, is the overall percentage starting a PhD per faculty as shown in Figure 3. The orange and blue bars show how these percentages are built up. In other words, they show how the percentage of alumni starting a PhD can be attributed to men and women. The figure shows that the percentage of alumni starting a PhD is highest among FPN alumni. Slightly over $30 \%$ of the alumni from FPN did start a PhD. This relatively high percentage is mainly driven by women. However, as we will see in later figures, this does not necessarily mean that women from FPN are more often starting a PhD than men who graduated from FPN, but that the group of women graduating from FPN is much larger than the group of men graduating from FPN. The percentage alumni starting a $\mathrm{PhD}$ is also higher than average among FHML and FHS graduates. Of the FASoS graduates, slightly over 10\% starts a PhD, and the percentage of alumni starting a PhD is even smaller among alumni from SBE and FdR. Taken all faculties together, the percentage of all UM master alumni who start a $\mathrm{PhD}$ is $17 \%$. 


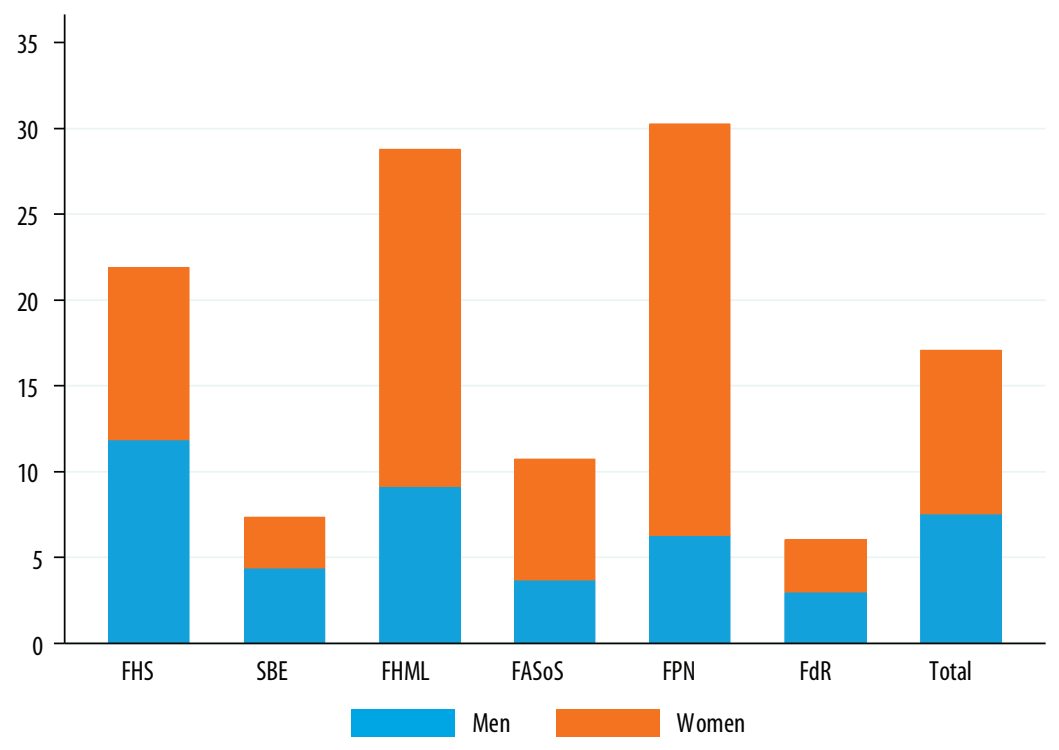

Source: NAE 2014, 2015, 2016, UM scanner 2014, 2015, 2016

In Figure 4, we see among those men and women who did start a PhD, from what faculties they graduated. FHML is the faculty from which most alumni did start a PhD. Of all female PhD graduates, 59\% graduated from FHML. Among male PhD graduates, this percentage is $50 \%$. Women who start a $\mathrm{PhD}$ are also likely to do so in the field of FPN (21\%), whereas men relatively often start a PhD in the field of SBE (21\%). Of all men and women starting a $\mathrm{PhD}$, the percentage of starting a $\mathrm{PhD}$ after graduation from FASoS is about $6 \%$, no clear gender differences here. Compared to women, men more often decide to start a PhD related to the field of FHS and FdR. 


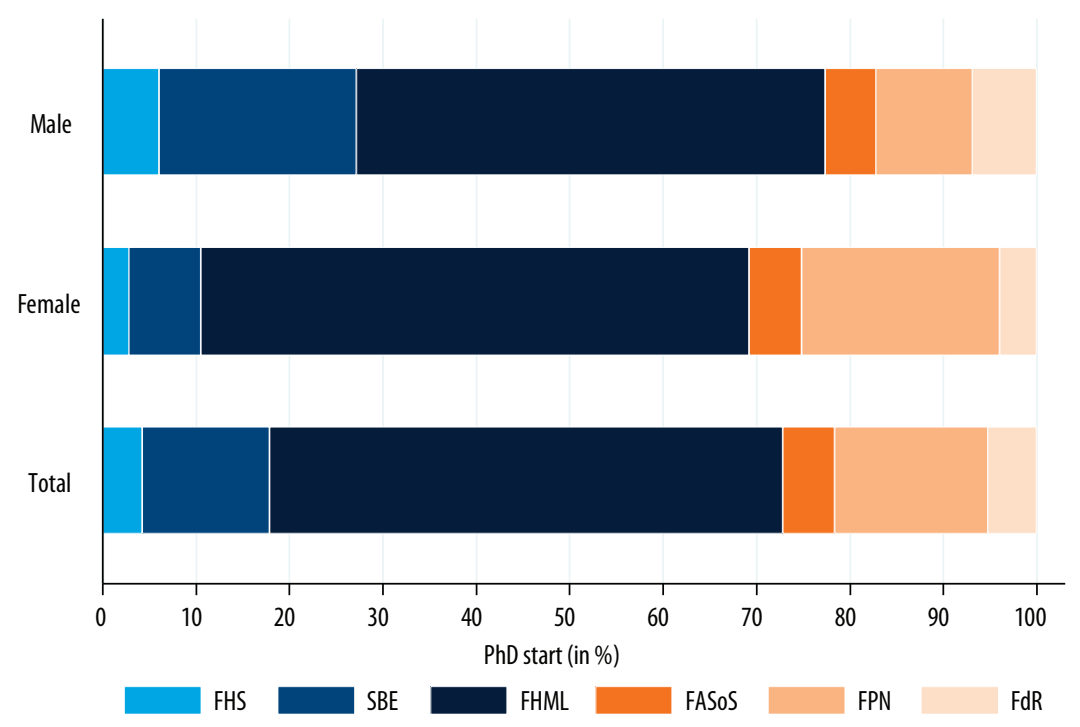

Source: NAE 2014, 2015, 2016, UM scanner 2014, 2015, 2016

In Figure 5, the percentages of male and female UM alumni are shown per graduation year, separately for the three groups of cohorts. It seems that starting a PhD was popular between 2009-2011, however, one should be careful with this interpretation as the timing of asking about

As the $T+1$ survey was a nationwide survey in 2015 (graduation cohort 2014), it is possible to see whether UM graduates do significantly start a PhD more or less than graduates in other universities. This turns out not to be case.

a PhD start differs across panel $a, b$ and $c$. In other words, the $T+1$ cohort could also start a $\mathrm{PhD}$ later than 1.5 years after graduation. ${ }^{14}$ However, the relatively low percentages of both men and women starting a PhD position in the graduation cohorts 2004-2006 compared to the cohorts 2009-2011 are likely to show that starting a PhD did indeed become more popular over time.

${ }_{14}$ We do not have information on the date starting a $\mathrm{PhD}$ position. 

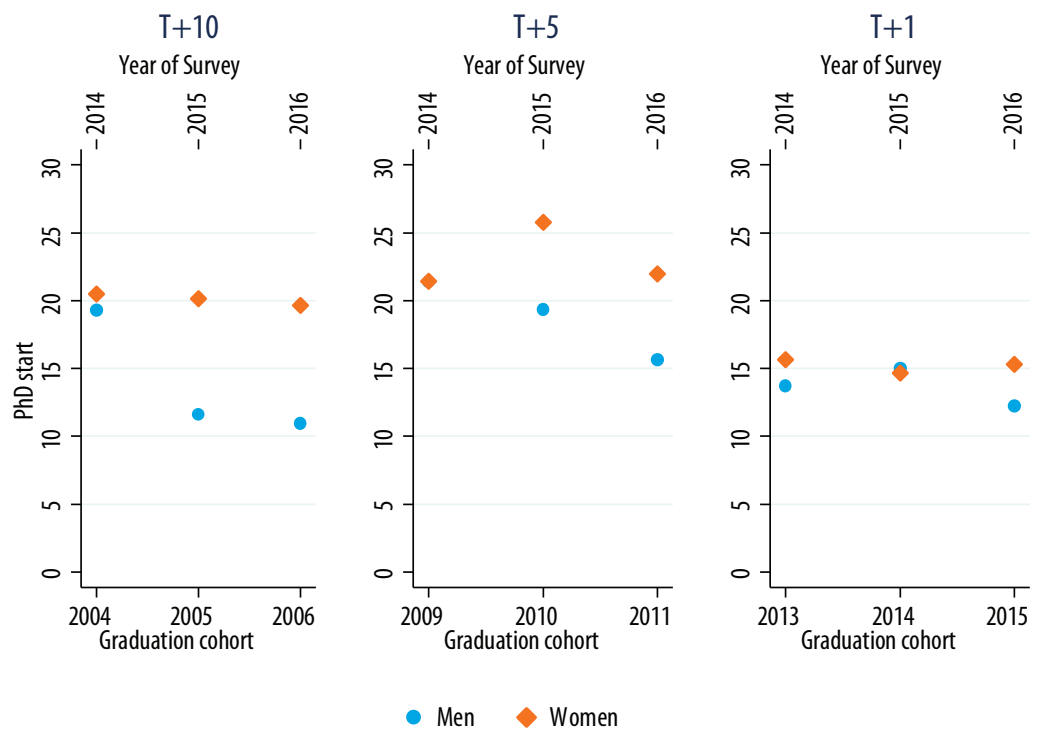

Source: NAE 2014, 2015, 2016, UM scanner 2014, 2015, 2016

So taken together, women do start a PhD more often than men. In Table 2 we include potential determinants to see whether we can explain why women do start a PhD more often than men. Is this due to a different view women have with respect to their followed education? Or is the difference due to differences in job preferences? Or are different personality characteristics driving the difference between men and women when it comes to starting a PhD? Since the nine cohorts we use in this report are collected with three different questionaires, we perform three different analyses.

In the analyses, we also control for university dummies. Because the UM is chosen as the reference category, we can interpret the coefficient on female as the gap between starting a PhD between male and female UM graduates. Similar to Figure 5, there is only a weak significant gender difference in starting a $\mathrm{PhD}$ among graduates from the cohort 2014. However, when we control for standard characteristics like age, internship and average grade, the difference gets significant at the $5 \%$ level. 
TABLE 2 Determinants of starting a PhD with a focus on gender difference and educational characteristics

\begin{tabular}{|c|c|c|c|}
\hline Dep. Var. Starting a PhD & (1) & (2) & (3) \\
\hline Female & $-0.0127^{*}$ & $-0.0187^{* *}$ & -0.00703 \\
\hline Age & & $-0.00231^{* * *}$ & $-0.00397^{* * *}$ \\
\hline Internship & & $0.0505^{* * *}$ & $0.0308^{* * *}$ \\
\hline Average grade & & $0.0732^{* * *}$ & $0.0630^{* * *}$ \\
\hline \multicolumn{4}{|l|}{ Satisfaction with: } \\
\hline Content of the programme & & & 0.00327 \\
\hline Acquired general skills & & & $-0.0121^{* *}$ \\
\hline Acquired academic skills & & & 0.00473 \\
\hline Breadth of the programme & & & -0.00433 \\
\hline Depth of the programme & & & -0.00170 \\
\hline Level of difficulty of the programme & & & 0.00123 \\
\hline Relationship between theory and practice & & & $0.0499^{* * *}$ \\
\hline Coherence w.r.t content & & & $-0.0289^{* * *}$ \\
\hline International orientation of the programme & & & 0.00635 \\
\hline Preparation for prof. practice & & & $0.0108^{* *}$ \\
\hline Gaining relevant prof. skills & & & $0.0240^{* * *}$ \\
\hline Getting in touch with the prof. practice & & & $0.0105^{* *}$ \\
\hline Knowledge of your teachers w.r.t. practice & & & 0.00114 \\
\hline Information on career options & & & -0.00366 \\
\hline Constant & $0.156^{* * *}$ & $-0.104^{* * *}$ & $-0.192^{* * *}$ \\
\hline Observations & 7.792 & 7.792 & 7.792 \\
\hline R-squared & 0.017 & 0.090 & 0.121 \\
\hline
\end{tabular}

Standard errors in parentheses

${ }^{* * *} p<0.01,{ }^{* *} p<0.05,{ }^{*} p<0.1$

Dummy variables for universities are included as well, the UM is taken as reference category.

Thereby, the female dummy can be seen as the gender difference among UM alumni.

Source: NAE 2015

Women have a $2 \%$ smaller probability of starting a PhD than men. The older a graduate is, the smaller the probability that they started a PhD position. Graduates who did an internship have a larger probability of starting a PhD..$^{15}$ Moreover, the higher the average grade during the Masters, the higher the probability of starting a PhD. This latter is probably related to the selection criteria of a $\mathrm{PhD}$ position. Satisfaction of the educational programme attended by the alumni also seems to play a role in explaining why some alumni start a PhD and others do not. Alumni who are satisfied with the relationship between theory and practice, with the preparation for professional practice, the acquired relevant professional skills and the way in which they got in touch with the

15 Unfortunately, we do not have indept information about the internship type. 
professional practice have a larger probability of starting a $\mathrm{PhD}$ position. Alumni who are satisfied with the acquired general skills and who are satisfied with the coherence with respect to the contact of the study programme are less likely to have started a $\mathrm{PhD}$ position. ${ }^{16}$

In Table 3 we analyse to what extent the gap between men and women in starting a PhD among the cohorts 2005 and 2010 can be explained by personality. Remember, that in these cohorts women significantly more often started a PhD than men (see also Figure 5). This can also be seen in Column (1) of Table 3. On average, women have a $9 \%$ larger probability of starting a PhD. Someone's nationality and the existence of children does not affect the start of a PhD. As we have seen in Table 2, age does. The older the graduate is, the smaller the probability of starting with a PhD (column 2). In Column (3), personality traits are included. Of the Big5 personality traits, extraversion and neuroticism seem to matter in starting a $\mathrm{PhD}$ position. Those who are more extravert, have a smaller probability of starting a PhD. Alumni who score high on neuroticism have a larger probability of starting a PhD. Table 3 also shows a relation between risk preference and starting a $\mathrm{PhD}$ : those who really like to take risks have a lower probability of starting a PhD position. Even though we observe that personality is related to starting a PhD position, the difference between men and women in starting a PhD does not change.

TABLE 3 Determinants of starting a PhD with a focus on gender difference and personality

\begin{tabular}{|c|c|c|c|}
\hline & (1) & (2) & (3) \\
\hline Female & $0.0872^{* * *}$ & $0.0824^{* * *}$ & $0.0881^{* * *}$ \\
\hline Age & & $-0.00556^{* *}$ & $-0.00440^{*}$ \\
\hline children & & 0.00166 & -0.00287 \\
\hline Dutch nationality & & -0.0122 & -0.0281 \\
\hline \multicolumn{4}{|l|}{ Personality } \\
\hline Conscientiousness & & & 0.0237 \\
\hline Extraversion & & & $-0.0381^{*}$ \\
\hline Agreeableness & & & 0.0203 \\
\hline Neuroticism & & & $0.0315^{* *}$ \\
\hline Openness to experience & & & 0.0227 \\
\hline Time preference & & & 0.0207 \\
\hline Risk preference & & & $-0.0444^{* *}$ \\
\hline Constant & $0.138^{* * *}$ & $0.352^{* * *}$ & 0.167 \\
\hline Observations & 770 & 770 & 770 \\
\hline R-squared & 0.012 & 0.024 & 0.048 \\
\hline
\end{tabular}

*** $\mathrm{p}<0.01,{ }^{* *} \mathrm{p}<0.05,{ }^{*} \mathrm{p}<0.1$

Source: UM scanner 2015

Dummy for $\mathrm{T}+10$ cohort included

16 We do not interpret these findings as causal because it might also be the case that the retrospective satisfaction of alumni depends on whether or not they started a PhD. 
In Table 4, yet another sample is used to analyse what drives the relation between gender and starting a PhD position. Table 4 is based on four graduation cohorts: 2004, 2006, 2009, and 2011. Compared to Tables 2-3, Table 4 includes variables on job preferences. Whereas women in these graduation cohorts have a larger probability of starting a PhD, this relation disappears when including nationality and an indicator showing whether the alumni did an internship. Those who did an internship before graduating, have a larger probability of starting a PhD position (in line with findings in Table 2). Additionally, we see that job preferences matter. Those who value job security, the opportunity to work internationally, good career prospects and want to do something useful for society, have a larger probability to start a $\mathrm{PhD}$ position. Alumni, who value high earnings, have a lower probability of starting a $\mathrm{PhD}$ position. These job characteristics fully explain the gender difference in starting a PhD. ${ }^{17}$

TABLE 4 Determinants of starting a PhD with a focus on gender difference and job preferences

\begin{tabular}{|l|c|c|c|}
\hline Dep. Var. Starting a PhD & $(1)$ & $(2)$ & $(3)$ \\
\hline Female & $0.0438^{* * *}$ & 0.0215 & 0.000621 \\
\hline Age & & -0.000212 & -0.000791 \\
\hline Children & & 0.00106 & 0.0189 \\
\hline Dutch nationality & & $-0.0443^{* *}$ & -0.0238 \\
\hline Internship & & $0.138^{* * *}$ & $0.124^{* * *}$ \\
\hline Job preferences: & & \\
\hline Work autonomy & & & -0.0149 \\
\hline Job security & & & $0.0333^{* * *}$ \\
\hline Opportunity to learn new things & & & 0.0148 \\
\hline Opportunity to work internationally & & & $0.0324^{* * *}$ \\
\hline High earnings & & & $-0.0400^{* * *}$ \\
\hline New challenges & & & -0.0202 \\
\hline Good career prospects & & & $0.0221^{*}$ \\
\hline Social status & & & -0.00123 \\
\hline Chance of doing something useful for society & & & \\
\hline Good chances to combine work with family & & & $0.0457^{* * *}$ \\
\hline Constant & & & -0.00691 \\
\hline Observations & & & -0.0576 \\
\hline R-squared & & & \\
\hline
\end{tabular}

*** $p<0.01,{ }^{* *} p<0.05,{ }^{*} p<0.1$

Source: UM scanner 2014, 2016

Year dummies and cohort dummies are included.

17 A regression in which only job preferences are included, leaving out nationality and internship, also results in an insignificant gender dummy. 


\section{4 \\ OBTAINING A PHD TITLE}

Now that we know that women do start a PhD more often than men, we continue by analysing whether they also more often obtain a PhD title. Figure 6 shows the percentage UM alumni who have obtained a PhD title by the time they were surveyed. This could be either 5 or 10 years after graduation. In Figure 6 we observe that women do obtain a PhD title more often than men. Of all female alumni $13 \%$ obtained a PhD which is significantly higher than the $9 \%$ male alumni who did obtain a $\mathrm{PhD}$ title.

The respondents in the $T+5$ and $T+10$ surveys of 2014 and 2016 who started a $\mathrm{PhD}$, were asked whether they successfully completed a $\mathrm{PhD}$, are still working on a PhD, or started but stopped with a PhD. $41 \%$ of the UM

Men and women have the same probability of quitting a PhD without obtaining the PhD title. .

alumni who did start a PhD did not finish their PhD yet. ${ }^{20}$ The majority of the alumni that did not finish yet is still working on their PhD (79\%). The remaining 21\% stopped before finishing it.

20 By the time they were surveyed, so 5 or 10 years after graduation. 


\section{FIGURE 6 Differences in obtaining a PhD title, per gender}

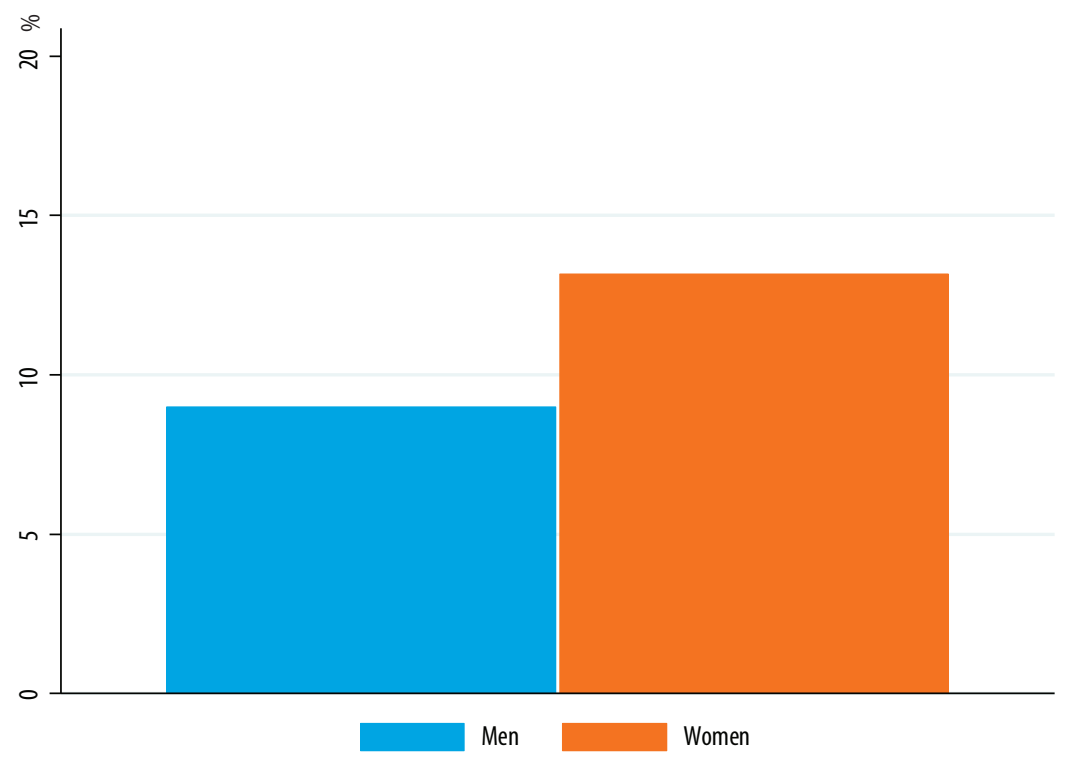

Source: UM scanner 2014, 2015, 2016

In Figure 7, the gender gap in obtaining a PhD title is shown per graduation cohort ( 5 and 10 years after graduation). As it turns out, in every cohort the percentage women with a $\mathrm{PhD}$ title is higher than the percentage men with a $\mathrm{PhD}$ title. Only for the graduation cohorts 2005 and 2006 this difference between men and women is significant. As we use information from alumni 5 and 10 years after graduation, one should be careful with interpreting the development over time, just like in Figure 5. 
FIGURE 7 Gender gap in obtaining a PhD title, per graduation cohort

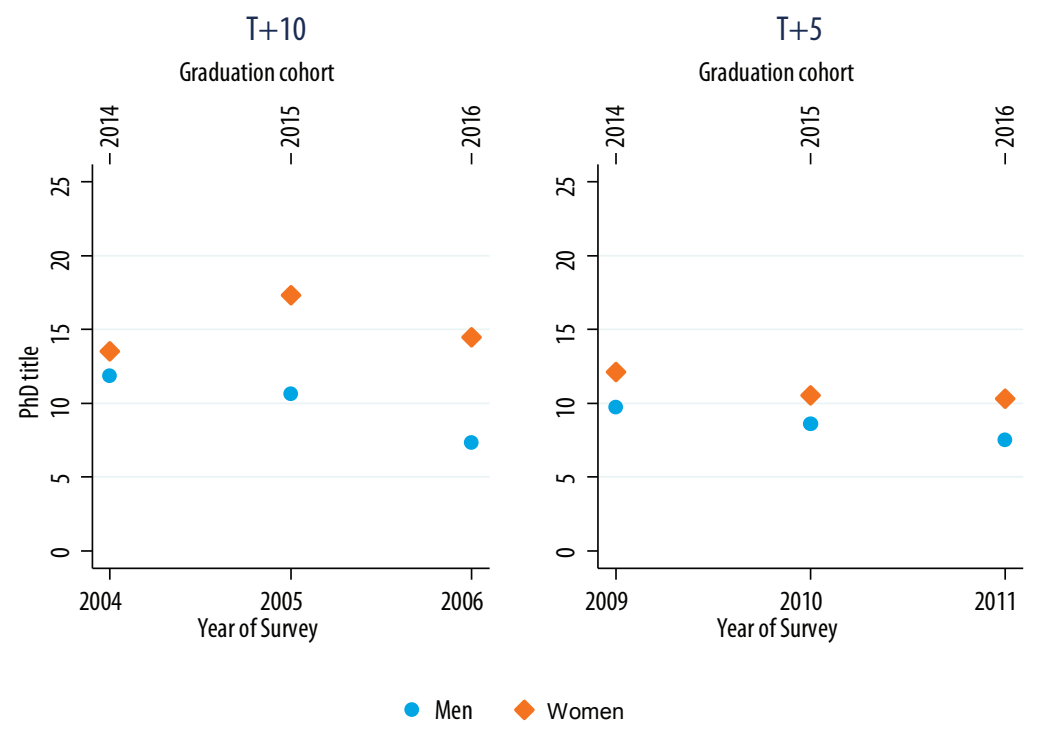

Source: UM scanner 2014, 2015, 2016 



\section{5 \\ CONTINUING AN ACADEMIC CAREER AFTER THE PHD}

Women start a $\mathrm{PhD}$ more often than men which also translates into a higher percentage female UM alumni having obtained a PhD title. However, the question remains whether women also use their PhD title more often to continue their academic career. Figure 8 shows the percentage UM alumni with a PhD title, working for an academic organisation and in an academic position. An academic organisation is defined as a university, an institute or an hospital. The considered academic positions are Post-doc, Assistant professor, Associate professor, Extraordinary professor and Full professor.

FIGURE 8 Differences in working for an academic organisation and in an academic position, per gender

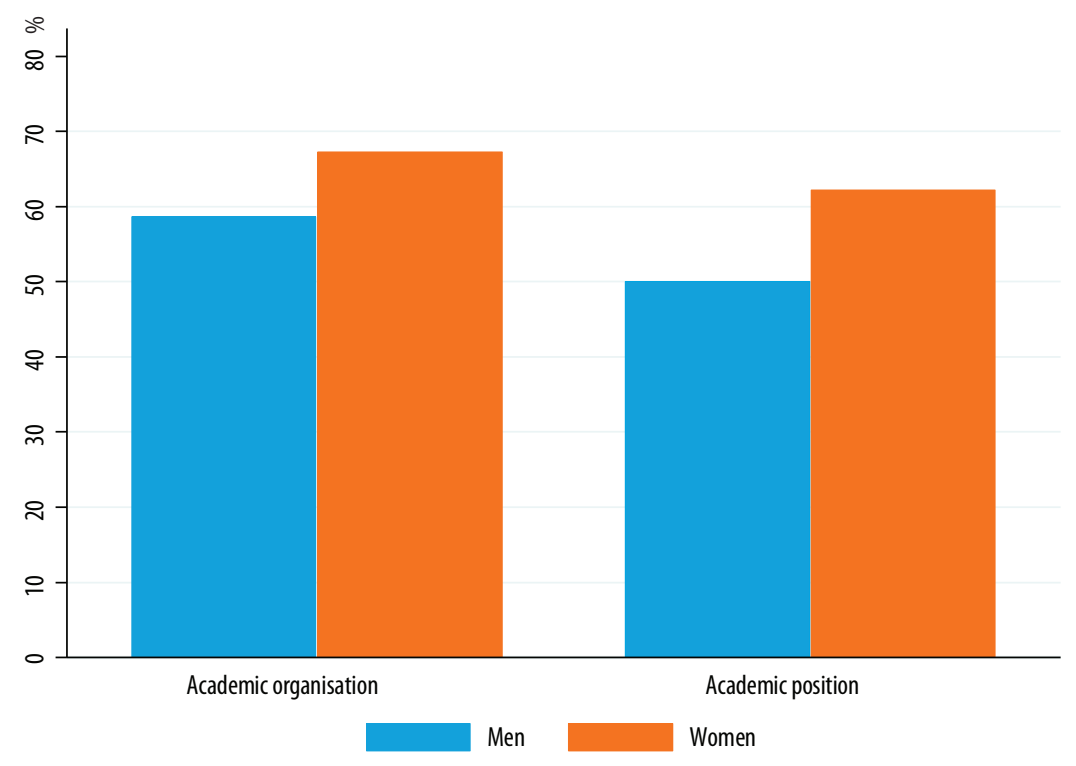

Source: UM scanner 2014, 2016 
After obtaining a $\mathrm{PhD}$ title $67 \%$ of the female UM alumni started working in an academic organisation. For male alumni this percentage is $56 \%$, but is not $57 \%$ of the UM alumni with a PhD title working for an academic organisation works at a university. There is no significant gender difference in working at a university.

significantly different than for female alumni. When working in an academic organisation $50 \%$ of the male UM alumni has an academic position. Among female UM alumni, $62 \%$ works in an academic position but again the difference is not significant. This is most likely due to the small number of observations. ${ }^{22}$.

So even though women more often start and finish a PhD, we do not observe significant differences between men and women in terms of continuing their academic career. In Table 5 we include background characteristics and job preferences in order to see what determines whether UM alumni with a PhD title work in an academic organisation or in an academic position. The table is based on four graduation cohorts: 2004, 2006, 2009, and 2011. The dependent variable in column 1 is working in an academic organisation (versus non-academic organisation) and in column 2 the dependent variable is working in an academic position (versus another, non-academic position).

22 The question whether or not someone works in an academic organisation has been answered by 87 male alumni and 153 female alumni. 48 male and 82 female alumni answered the question concerning the position they have. 
TABLE 5 Determinants of continuing an academic career with a focus on gender difference and job preferences

\begin{tabular}{|l|c|c|}
\hline Dep. Var.: & $\begin{array}{c}\text { Working in academic } \\
\text { organisation }\end{array}$ & $\begin{array}{c}\text { Working in an academic } \\
\text { position }\end{array}$ \\
\hline Female & 0.0623 & 0.118 \\
\hline Age & 0.0116 & $-0.0354^{* *}$ \\
\hline Children & 0.0397 & -0.136 \\
\hline Dutch nationality & $0.199^{* * *}$ & -0.149 \\
\hline Internship & 0.0320 & 0.0650 \\
\hline Job preferences: & & \\
\hline Work autonomy & 0.0568 & 0.0686 \\
\hline Job security & $0.0826^{* *}$ & $0.111^{*}$ \\
\hline Opportunity to learn new things & -0.00275 & -0.0359 \\
\hline Opportunity to work internationally & $0.0582^{* *}$ & $0.113^{* * *}$ \\
\hline High earnings & $-0.0971^{* *}$ & -0.0442 \\
\hline New challenges & -0.0622 & 0.0621 \\
\hline Good career prospects & -0.0384 & -0.121 \\
\hline Social status & 0.0476 & 0.0542 \\
\hline Chance of doing something useful for society & 0.0556 & -0.0853 \\
\hline Good chances to combine work with family & -0.0538 & 0.0263 \\
\hline Constant & 0.0185 & $1.235^{* *}$ \\
\hline Observations & & 126 \\
\hline R-squared & 234 & 0.326 \\
\hline (a) & 0.138 & \\
\hline
\end{tabular}

*** $\mathrm{p}<0.01,{ }^{* *} \mathrm{p}<0.05,{ }^{*} \mathrm{p}<0.1$

Source: UM scanner 2014, 2016

Year dummies and cohort dummies are included

Column 1 in table 5 shows that age, having children, and having followed an internship during the master does not determine working in an academic organisation. The nationality of UM alumni however is related to the probability of working in an academic organisation; alumni with a Dutch nationality are more likely to work for an academic organisation. Concerning job preferences we see that alumni with a PhD title who value job security and the opportunity to work internationally are more likely to work for an academic organisation. On the other hand, alumni with a PhD title who value high earnings have a lower probability to work for an academic organisation.

Column 2 shows a negative relation between age and working in an academic position. The older on is, the smaller the probability of working in an academic position. Having children or having followed an internship during the masters does not seem to relate to the probability of working in an academic position. Furthermore we find that alumni who value job security and the opportunity of working internationally are more likely to work in an academic position. 



\section{6 \\ GENDER DIFFERENCES IN JOB QUALITY BETWEEN MALE AND FEMALE ALUMNI WITH A PHD}

While the data did not show any gender differences for those who chose an academic career after completing their $\mathrm{PhD}$, there might be a difference in overall job quality compared to their male peers. Figure 9 shows differences in a number of work characteristics between male and female workers with a PhD: their average hourly wage, job satisfaction, career opportunities, supervision tasks and the percentage of full-time workers. ${ }^{24}$

24 Hourly wages are trimmed at the $1 \%$ and $99 \%$ level. A full-time job is defined as working at least 35 hours per week. 
FIGURE 9 Differences in job quality measured in percentages, per gender
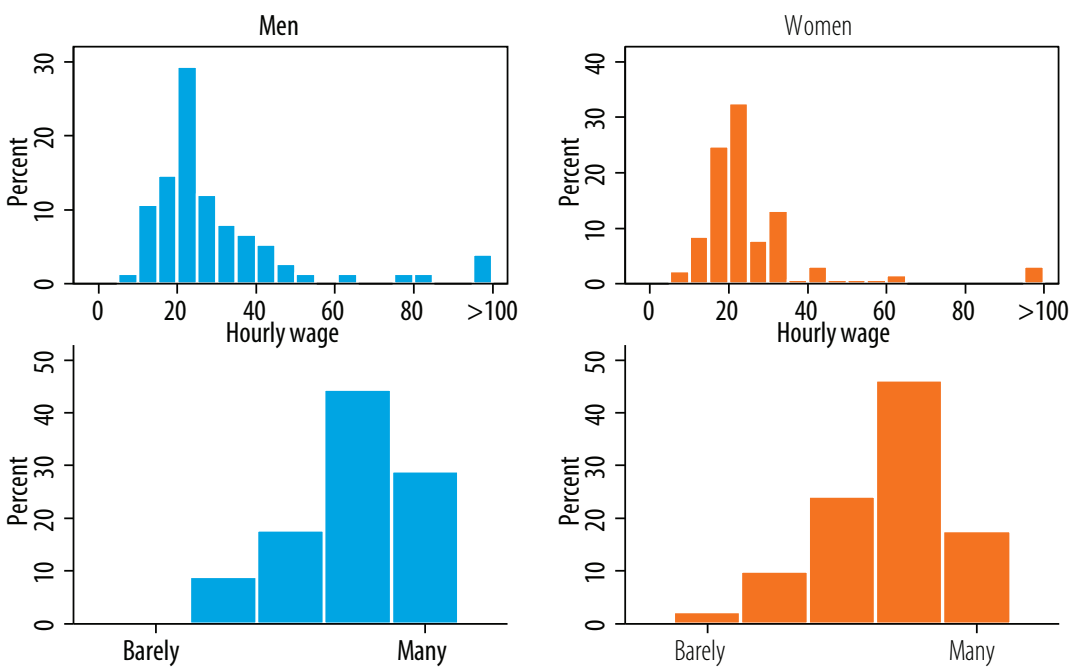

Does your workplace profide good career opportunities? Does your workplace profide good career opportunities?
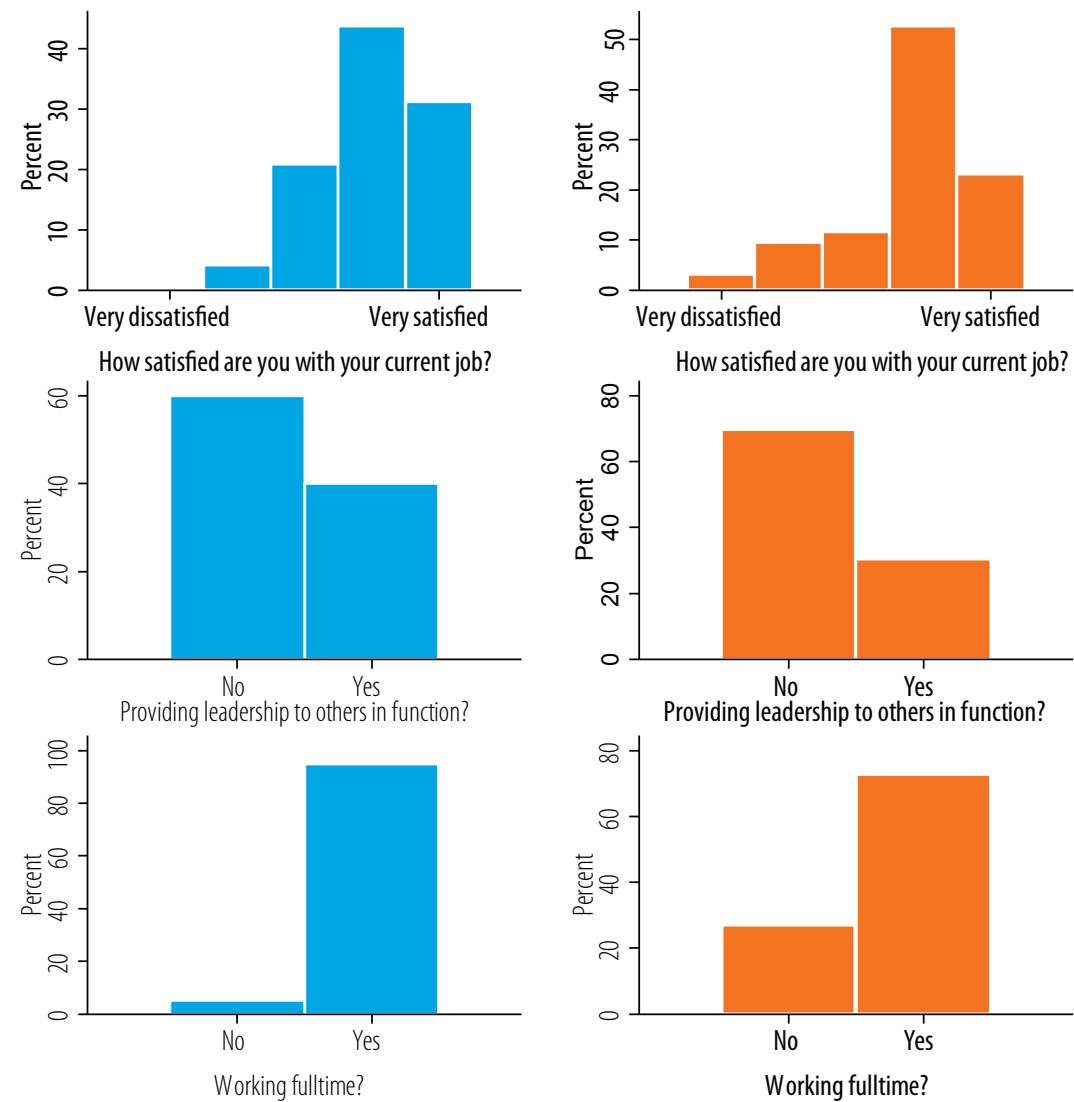

Source: UM scanner 2014, 2016 
For all measures, males score significantly higher than females, although not all differences might be significantly different once we control for several factors. Therefore, we estimate whether a gender gap remains when performing regressions in which we control for standard characteristics and job preferences..$^{25}$ Moreover, we add an analysis for those who did not obtain a PhD. Doing so allows a comparison between those with and without a PhD when it comes to gender differences. From this we can conclude whether obtaining a PhD makes a difference with respect to the gender gap.

Table 7 shows the results for hourly wage ${ }^{26}$, and is divided in two parts. Models (1) and (2) show results about graduates who obtained a $\mathrm{PhD}$, while model (3) is about graduates without a $\mathrm{PhD}$. For those with a $\mathrm{PhD}$, there is no significant difference in gender with regards to wage in both models. Differences in wages between $\mathrm{PhD}$ graduates are mainly due to age and to a smaller extent also to the degree to which someone views autonomy, career prospects, social status and the chance of doing something useful for society as important.

For those without a PhD we actually do find a statistically significant wage penalty for woman. Women seem to earn around 9\% less than men, even when taking standard personal characteristics and job preferences into account. Furthermore, lots of other characteristics also are significantly related to the wage of non-PhDs. Those who care about high earnings are also more likely to self-select themselves into jobs with a higher wage, while those who focus on other job characteristics (job security, doing something useful for society) have a lower wage. Likewise, having done an internship also gives a boost to hourly wage. Interesting enough, working more hours has a negative effect on hourly wage, albeit very small. This might be a result from jobs with a high number of working hours per week, like setting up a new business or consulting jobs. Such jobs might need some time before they actually pay off compared to other jobs.

25 We focus on job preferences to explain gender differences as personality and educational characteristics are not available for the $\mathrm{T}+10$ cohorts. These cohorts are necessary for our analyses in which we distinguish PhD and non-PhD graduates.

26 In the model we take log wage as a dependent variable, allowing the coefficients to be interpreted as percentages. 
TABLE 7 Determinants of hourly wage for (non-) PhD graduates with a focus on gender difference and job preferences

\begin{tabular}{|c|c|c|c|}
\hline \multirow[t]{2}{*}{ Dep. Var. Log-hourly wage } & \multicolumn{2}{|c|}{ PhDs } & \multirow{2}{*}{$\begin{array}{l}\text { Non-PhDs } \\
\text { (3) }\end{array}$} \\
\hline & (1) & (2) & \\
\hline Female & 0.110 & 0.0569 & $-0.0917^{* * *}$ \\
\hline Age & -0.000598 & $0.194^{* *}$ & $0.0381^{*}$ \\
\hline $\mathrm{Age}^{2}$ & & $-0.00241^{* *}$ & -0.000353 \\
\hline Children & 0.0805 & 0.0895 & 0.0331 \\
\hline Internship & & -0.0292 & $0.0638^{* *}$ \\
\hline Job hours, per week & & -0.00398 & $-0.00271^{* *}$ \\
\hline \multicolumn{4}{|l|}{ Job preferences: } \\
\hline Work autonomy & & $0.107^{*}$ & 0.0203 \\
\hline Job security & & 0.0228 & $-0.0389^{* * *}$ \\
\hline Opportunity to learn new things & & 0.0168 & -0.00987 \\
\hline Opportunity to work internationally & & -0.0390 & 0.00592 \\
\hline High earnings & & 0.0743 & $0.0948^{* * *}$ \\
\hline New challenges & & 0.0267 & -0.00834 \\
\hline Good career prospects & & $-0.135^{*}$ & 0.0277 \\
\hline Social status & & $0.0992^{* *}$ & -0.00598 \\
\hline Chance of doing something useful for society & & $0.0954^{*}$ & $-0.0350^{* * *}$ \\
\hline Good chances to combine work with family & & -0.0592 & 0.0108 \\
\hline Constant & $3.523^{* * *}$ & -0.655 & $2.225^{* * *}$ \\
\hline Observations & 204 & 200 & 1.651 \\
\hline R-squared & 0.187 & 0.283 & 0.209 \\
\hline
\end{tabular}

*** $p<0.01,{ }^{* *} p<0.05,{ }^{*} p<0.1$

Source: UM scanner 2014, 2016

Model: OLS

Year dummies and cohort dummies are included

In Table 8, we analyse job satisfaction. As before, the table shows results for both alumni with and without a PhD. For those with a PhD, we see no significant difference between males and females in the first model, but a negative coefficient with regards to gender in the second model, suggesting that woman with a $\mathrm{PhD}$ are more likely to have a lower job satisfaction. However, this difference is only weakly significant, which might be due to the low number of observations. Furthermore, $\mathrm{PhD}$ graduates who prefer jobs with new challenges or jobs in which there is a chance for doing something useful for society, have a higher job satisfaction. 
TABLE 8 Determinants of job satisfaction for (non-)PhD graduates with a focus on gender difference and job preferences

\begin{tabular}{|c|c|c|c|}
\hline \multirow[t]{2}{*}{ Dep. Var. Job Satisfaction } & \multicolumn{2}{|c|}{ PhDs } & \multirow{2}{*}{$\begin{array}{l}\text { Non-PhDs } \\
\text { (3) }\end{array}$} \\
\hline & (1) & (2) & \\
\hline Female & -0.437 & $-0.742^{*}$ & $-0.350^{* * *}$ \\
\hline Age & -0.00520 & -0.0954 & $-0.204^{* *}$ \\
\hline $\mathrm{Age}^{2}$ & & 0.000459 & $0.00209^{*}$ \\
\hline Children & -0.211 & 0.115 & $0.253^{*}$ \\
\hline Internship & & 0.266 & 0.121 \\
\hline Job hours, per week & & -0.0101 & $0.0227^{* * *}$ \\
\hline \multicolumn{4}{|l|}{ Job preferences: } \\
\hline Work autonomy & & -0.0679 & $0.163^{*}$ \\
\hline Job security & & -0.180 & 0.0890 \\
\hline Opportunity to learn new things & & -0.0575 & 0.120 \\
\hline Opportunity to work internationally & & -0.000274 & -0.0120 \\
\hline High earnings & & -0.204 & -0.0188 \\
\hline New challenges & & $0.666^{* *}$ & $0.253^{* *}$ \\
\hline Good career prospects & & -0.308 & -0.0776 \\
\hline Social status & & 0.186 & $-0.115^{*}$ \\
\hline Chance of doing something useful for society & & $0.584^{* *}$ & $0.120^{*}$ \\
\hline Good chances to combine work with family & & -0.338 & 0.0700 \\
\hline Observations & 142 & 138 & 1.214 \\
\hline
\end{tabular}

${ }^{* * *} p<0.01,{ }^{* *} p<0.05,{ }^{*} p<0.1$

Source: UM scanner 2014, 2016

Model: ordered logit model, dependent variable going from 1 (very dissatisfied) to 5 (very satisfied) Constants per cut-off, year dummies and cohort dummies are included

For alumni without a $\mathrm{PhD}$, the gender gap regarding job satisfaction is about half the size as for those with a PhD, however the difference is statistically significant. There is also a positive relation between job satisfaction and the number of hours worked per week and preferring new challenges. Those who are older have a relatively low job satisfaction. Other predictors are at most only weakly significant.

Table 9 shows the results for career opportunities. There seems to be no significant difference in perceived career opportunities between male and female workers with a PhD. In the first model there is a significant relation between age career opportunities on the one hand and age and having children on the other. However these relations lose power in column 2. It turns out that career opportunities are mostly related to job hours. 
For non-PhDs, the table show that female workers have less career opportunities than their male counterparts. Moreover, working more hours per week is related to larger career opportunities. As women on average work less hours, the descriptive difference between men and women is based on the combined gender and hours effect. Those who perceive career prospects as important, as well those who seek new challenges, report a higher amount of perceived career opportunities.

TABLE 9 Determinants of career opportunities for (non-) PhD graduates with a focus on gender difference and job preferences

\begin{tabular}{|l|l|l|l|}
\hline Dep. Var. Career opportunities & \multicolumn{2}{|c|}{ PhDs } & Non-PhDs \\
\hline Female & $(1)$ & $(2)$ & $-0.288^{* *}$ \\
\hline Age & -0.436 & -0.219 & 0.0167 \\
\hline Age ${ }^{2}$ & $-0.119^{* *}$ & -0.0253 & -0.000713 \\
\hline Children & & -0.00117 & 0.118 \\
\hline Internship & $-0.693^{*}$ & -0.498 & 0.115 \\
\hline Job hours, per week & & 0.732 & $0.0519^{* * *}$ \\
\hline Job preferences: & & $0.0470^{* *}$ & \\
\hline Work autonomy & & & 0.0442 \\
\hline Job security & & 0.324 & -0.0750 \\
\hline Opportunity to learn new things & & -0.373 & 0.000707 \\
\hline Opportunity to work internationally & & 0.122 & 0.0437 \\
\hline High earnings & & -0.00468 & 0.0477 \\
\hline New challenges & & $0.451^{*}$ & $0.311^{* * *}$ \\
\hline Good career prospects & & 0.118 & $0.0929^{* * *}$ \\
\hline Social status & & 0.0305 & -0.102 \\
\hline Chance of doing something useful for society & & 0.120 & $-0.136^{*}$ \\
\hline Good chances to combine work with family & & -0.0156 & 0.0940 \\
\hline Observations & & 0.196 & \\
\hline
\end{tabular}

*** $\mathrm{p}<0.01,{ }^{* *} \mathrm{p}<0.05,{ }^{*} \mathrm{p}<0.1$

Source: UM scanner 2014, 2016

Model: ordered logit model, dependent variable going from 1 (hardly) to 5 (many)

Constants per cut-off, year dummies and cohort dummies are included 
Taking a closer look: Wage decomposition for both genders

The Blinder-Oaxaca decomposition (Blinder 1973; Oaxaca 1973) is a statistical method to explain the wage differential between two different groups. This method provide insights in the degree to which wage differentials between men and women are due to observed differences in the predictor variables between men and women (like age, internship experience and job preferences). The remaining gender difference is due to unobserved predictors. These unobserved effects might be due to discrimination, but they can also reflect other differences between men and women that are not included in the model such as ability or effort.

Table A shows the results of the decomposition of the hourly wage variable between gender for all master graduates. ${ }^{27}$ Looking only at the difference between hourly wages per gender, we see a significant difference of 0.171 for all workers, and an insignificant difference for those with a PhD title, similar to what we observed in our regression model.

This difference is then split in three components: endowment, coefficients, and interaction. Endowment reflects the mean increase in wages for women if the predictors would be similar for both groups. Coefficients are the change one would get if the coefficients, the effect on hourly wage per extra unit, would be the same for men and women. Lastly, the interaction term measures the effect of the interaction of the first two components. Anything outside these three effects is due to unobserved effects.

TABLE A Decomposition of the gender difference in hourly wage

\begin{tabular}{l|c|}
\hline Dep. Var. log hourly wage & All graduates \\
\hline Overall & \\
\hline Mean log hourly wages (male) & $3.321^{* * *}$ \\
\hline Mean log hourly wages (female) & $3.150^{* * *}$ \\
\hline Differences & $0.171^{* * *}$ \\
\hline Endowments & $0.0659^{* * *}$ \\
\hline Coefficients & 0.0315 \\
\hline Interaction & $0.0732^{* * *}$ \\
\hline Observations & 1.851 \\
\hline$* * * \mathrm{p}<0.01{ }^{* *} \mathrm{p}<0.05{ }^{*} \mathrm{p}<0.1$ & \\
\hline
\end{tabular}

Source: UM scanner 2014, 2016

Model: Blinder-Oaxaca decomposition

Same controls are included as in Table 7

For all master graduates, we observe an effect of 0.171 in log wages, so women earn on average $17 \%$ less than men. Equal endowments would lead to an increase of about 0.066 . This means

27 As for PhDs, we observe no significant wage differential, there is no use in estimating a Blinder-Oaxaca decomposition for the $\mathrm{PhD}$ and non-PhD sample separately. 
that if men and women would be similar in age, hours worked, job preferences and all other included characteristics, there would not be a wage differential of $17 \%$ but of $7 \%$ only. This implies that $40 \%$ of the gender difference in wage is due to differences in characteristics of men and women. As can be seen in the appendix, especially the distribution of graduates across faculties, internship experience and the numbers of hours worked account for the gender difference in wage. As there is no significant coefficient effect, there turns out to be no overall discrimination based on the included characteristics (in other words, the coefficient between wage and the characteristics is similar for men and women). However, as can be seen in the appendix, there are some exceptions. For example, the relation between hours worked and wage is different for men and women. $20 \%$ of the wage differential between men and women are due to unexplained effects. This could mean that there is wage discrimination against women, but also that we do miss important variables explaining wage which are different between men and women.

In Table 10, we analyse the probability of supervising others. As with the other effects, we do not find a significant difference between men and woman with a PhD title. This time, however, we also do not find a significant gender difference for those without a PhD. Important for supervision is age, hours worked and a preference for autonomy and high earnings. Interestingly, graduates who view the combination of work and family life as important, have a smaller probability of having a supervising position. 
TABLE 10 Determinants of supervision for (non-) PhD graduates with a focus on gender difference and job preferences

\begin{tabular}{|c|c|c|c|}
\hline \multirow[t]{2}{*}{ Dep. Var. Supervising others } & \multicolumn{2}{|c|}{ PhDs } & \multirow{2}{*}{$\begin{array}{c}\text { Non-PhDs } \\
\text { (3) }\end{array}$} \\
\hline & (1) & (2) & \\
\hline Female & -0.233 & -0.0394 & -0.0703 \\
\hline Age & 0.0200 & 0.127 & $0.228^{* *}$ \\
\hline Age2 & & -0.00128 & $-0.00292^{* *}$ \\
\hline Children & -0.144 & -0.176 & $0.508^{* * *}$ \\
\hline Internship & & 0.190 & 0.00101 \\
\hline Job hours, per week & & $0.0312^{*}$ & $0.0605^{* * *}$ \\
\hline \multicolumn{4}{|l|}{ Job preferences: } \\
\hline Work autonomy & & -0.138 & $0.377^{* * *}$ \\
\hline Job security & & -0.124 & $-0.111^{*}$ \\
\hline Opportunity to learn new things & & -0.0331 & -0.157 \\
\hline Opportunity to work internationally & & 0.155 & -0.0224 \\
\hline High earnings & & -0.225 & $0.201^{* * *}$ \\
\hline New challenges & & 0.0906 & $0.176^{*}$ \\
\hline Good career prospects & & 0.0980 & 0.0172 \\
\hline Social status & & 0.215 & -0.00340 \\
\hline Chance of doing something useful for society & & -0.106 & -0.0818 \\
\hline Good chances to combine work with family & & 0.189 & $-0.165^{* * *}$ \\
\hline \multicolumn{4}{|l|}{$-8.511^{* * *}$} \\
\hline Constant & -0.731 & -4.917 & \\
\hline Observations & 262 & 256 & 2.091 \\
\hline
\end{tabular}

${ }^{* * *} p<0.01,{ }^{* *} p<0.05,{ }^{*} p<0.1$

Source: UM scanner 2014, 2016

Model: logit model

Year dummies and cohort dummies are included

Table 11 shows that women more often work part-time. This holds both for those with and without a PhD. Having children clearly lowers the probability to work full-time, as does the preference for combining work with family. A preference for working internationally on the other hand increases the probability to work full-time. 
TABLE 11 Determinants of a full-time job with a focus on gender difference and job preferences

\begin{tabular}{|l|c|c|c|}
\hline Dep. Var. Fulltime work & \multicolumn{2}{|c|}{ PhDs } & Non-PhDs \\
\hline Female & $(1)$ & $(2)$ & $-1.497^{* * *}$ \\
\hline Age & $-1.816^{* * *}$ & $-1.333^{* *}$ & 0.0903 \\
\hline Age2 & 0.0643 & 0.572 & -0.00134 \\
\hline Children & & -0.00707 & $-0.931^{* * *}$ \\
\hline Internship & $-2.095^{* * *}$ & $-1.395^{* *}$ & 0.207 \\
\hline Job preferences: & & 0.274 & 0.0771 \\
\hline Work autonomy & & & 0.521 \\
\hline Job security & & 0.0111 & -0.202 \\
\hline Opportunity to learn new things & & 0.0764 & $0.415^{* *}$ \\
\hline Opportunity to work internationally & & -0.191 & 0.541 \\
\hline High earnings & & $0.410^{* * *}$ & $0.733^{*}$ \\
\hline New challenges & & $0.312^{* * *}$ & -0.501 \\
\hline Good career prospects & & 0.0952 & 0.139 \\
\hline Social status & & $0.372^{* * *}$ & 0.00713 \\
\hline Chance of doing something useful & & -0.0791 & $-1.431^{* * *}$ \\
\hline for society & & 0.0727 & 0.521 \\
\hline Good chances to combine work with & & & \\
\hline family & & $-0.448^{* * *}$ & \\
\hline Constant & & -8.238 & \\
\hline Observations & & 215 & \\
\hline
\end{tabular}

${ }^{* * *} \mathrm{p}<0.01,{ }^{* *} \mathrm{p}<0.05,{ }^{*} \mathrm{p}<0.1$

Source: UM scanner 2014, 2016

Model: logit model

Year dummies and cohort dummies are included 


\section{7 \\ CONCLUSION}

In this report we have analysed the gender difference in academic careers of UM alumni. Three questions were central:

1. What are the gender differences in starting and continuing an academic career?

2. What are the gender differences in job quality of alumni with (and irrespectively of) a PhD?

3. How can possible gender differences in academic careers of UM alumni be explained?

It turns out that $17 \%$ of the UM alumni start a PhD. Of the male UM alumni $15 \%$ start a $\mathrm{PhD}$, whereas among female alumni $19 \%$ did start a PhD. This difference is statistically significant and in contrast to the statistics based on the Netherlands as a whole where women less often do a PhD than men.28 Of all female graduates who started a PhD, $59 \%$ obtained a masters from FHML. Women who start a PhD are also likely to do so in the field of FPN (21\%), whereas men relatively often start a PhD in the field of SBE (21\%).

In eight out of the nine cohorts under scrunity, the percentage of female UM alumni starting a $\mathrm{PhD}$ is higher than the percentage of male UM alumni starting a PhD. It turns out that job preferences can explain this difference completely. Especially job security, opportunity to work internationally, having the chance to do something useful for society and a relatively low preference for high earnings turn out to be related to starting a PhD.

The percentage of women obtaining a $\mathrm{PhD}$ title is, as a consequence of a higher percentage who starts with a PhD and a similar dropout percentage, higher among female than male UM alumni. There is also no significant difference in the type of organisation male and female UM alumni with a PhD title end up. After obtaining a PhD title, $67 \%$ of the female UM alumni started working in an academic organisation.

Similar to the absence of any gender differences for those who chose an academic career after completing their $\mathrm{PhD}$, we neither find clear differences in overall job quality. For wages, perceived career opportunities and supervision tasks, we do not find differences

28 Monitor vrouwelijke Hoogleraren 2017 
between male and female UM alumni with a PhD title. Where we do find a smaller job satisfaction of women compared to men, the significance levels areweak. The absence of clear gender differences in overall job quality is remarkable as for the sample of UM graduates who do not have a PhD title we actually do find significant and sizable differences. The only gender difference which also holds for those with a PhD title is the working hours per week. Women do have a significant smaller probability of working full-time, even after controlling for having children and having a preference for combining work with family life.

Overall, we conclude that after obtaining a PhD, there are at most only weakly significant differences in the other job quality measures between men and women who graduated (their masters) from the UM, suggesting that a $\mathrm{PhD}$ title seems to decrease or even completely closes the gender gap. ${ }^{29}$

29 We have to keep in mind the small number of observations for the PhD graduate sample. Nevertheless, most often also the (sign and/or) size of the coefficient was not comparable to the non-PhD sample. 


\section{APPENDIX}

TABLE A1 The gender difference in explaining log-hourly wage, using Blinder-Oaxaca decomposition, detailed results

\begin{tabular}{|c|c|c|c|}
\hline \multirow[t]{2}{*}{ Dep. Var. log hourly wage } & \multicolumn{3}{|c|}{ Full model } \\
\hline & Endowment & Coefficients & Interaction \\
\hline Age & 0.0314 & -1.344 & -0.0210 \\
\hline Age2 & -0.0191 & 0.750 & 0.0187 \\
\hline Children & -0.000166 & 0.00678 & $-6.89 e-05$ \\
\hline Faculty effects & $0.0708^{* * *}$ & -0.0256 & $-0.0371^{*}$ \\
\hline Internship & $-0.0171^{* * *}$ & $-0.0539^{*}$ & $0.0166^{*}$ \\
\hline Huidige functie totaal aantal arbeidsuren & $-0.0365^{* * *}$ & $0.205^{* *}$ & $0.0368^{*}$ \\
\hline Job preferences: & 0.00276 & -0.0210 & -0.000400 \\
\hline Work autonomy & 0.00512 & -0.0999 & 0.00784 \\
\hline Job security & 0.000280 & 0.169 & -0.000449 \\
\hline Opportunity to learn new things & -0.00686 & $0.103^{*}$ & $0.0218^{*}$ \\
\hline Opportunity to work internationally & $0.0316^{* * *}$ & 0.137 & 0.0168 \\
\hline High earnings & -0.00406 & $0.287^{*}$ & 0.00611 \\
\hline New challenges & 0.00313 & -0.0272 & -0.000820 \\
\hline Good career prospects & -0.000791 & 0.0450 & 0.00166 \\
\hline Social status & 0.000979 & -0.139 & 0.0143 \\
\hline Chance of doing something useful for society & 0.00496 & 0.0957 & -0.00679 \\
\hline Good chances to combine work with family & 0.0314 & -1.344 & -0.0210 \\
\hline Constant & & -0.0609 & \\
\hline
\end{tabular}

Source:UM

Year dummies and cohort dummies are included 


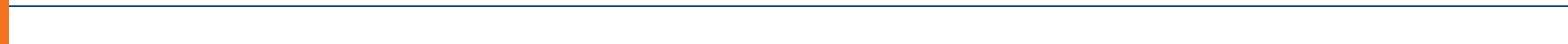

36 BIJLAGE 